\title{
THE EFFECT OF RIPARIAN FOREST SHADE ON THE STRUCTURAL CHARACTERISTICS OF MACROPHYTES IN A MID-FOREST LAKE
}

\author{
SENDER, J. \\ University of Life Sciences in Lublin, Department of Landscape Ecology and Nature Protection \\ Dobrzańskiego B. st. 37, 20-262, Lublin, Poland \\ (phone: +48-607-372-614) \\ Corresponding author \\ e-mail: joanna.sender@up.lublin.pl \\ (Received $3^{\text {rd }}$ Oct 2014; accepted $5^{\text {th }}$ May 2016)
}

\begin{abstract}
The aim of the study was to evaluate whether riparian trees limit growth of aquatic plants in lakes. In the studied lake, sections of the littoral zone were shaded to different degrees. The maximum extent of shading in the studied lake did not exceed $15 \mathrm{~m}$. Regardless of the amount of light reaching the lake three groups of macrophytes developed. The data suggest that shading by riparian vegetation was not limiting to growth of all aquatic plants in the studied lake but did significantly limit development of macrophyte communities. The extent of shading was correlated with both the structure of macrophyte communities in addition to their range. In shady areas density, colonization depth, biomass and diversity index of emergent macrophytes were significantly lower. Submerged macrophytes in the lake were generally outside the scope of shadow impact. Only macrophytes occurring between 0.5 and $1 \mathrm{~m}$ depth were influenced by shade. Generally, submerged macrophyes were outside of the influence of shade. However, along the northern shore, lush growth of adjacent rushes may have effected submerged macrophytes and in these areas their measured values (biomass, density, abundance) were lower. In the southern part of the lake, rushes achieve lower density and extent of occurrence, but submerged macrophytes grew better, and both biomass and species richness were higher than along northern shores.

Keywords: macrophytes, mid - forest lake, riparian vegetation, biomass, shading
\end{abstract}

\section{Introduction}

Light is a key driving factor of life in aquatic ecosystems. Light penetration influences many processes regulated by "e.g. water density and viscosity, the solubility of solids and gases and the rate of metabolic processes in plants (Chełmicki, 2001; Squires et al., 2002; Sevindik and Celik, 2014). The temperature tolerance range of individual plant species is genetically fixed and most freshwater macrophytes appear to be eurythermic (Madsen and Brix, 1997; Feldmann, 2012).

Light availability is a critical environmental factor determining the growth of macrophyte communities and their species richness (Lacoul and Freedman, 2006). Light can also influence community composition, as well as zonation within a water body (Wersal and Madsen, 2013). In some cases, shading leads to the elimination of both emergent and submerged macrophytes (Bernatowicz, 1966). Submerged aquatic plants have morphological adaptations to colonizing and establishing populations in low light environments (Barko et al., 1986). The quantity of light reaching the water is especially important for these species, because in aquatic habitats light rays reaching plants is significantly reduced (Chambers and Kalff, 1985; Lehmann and Lachavanne, 1999; Sender, 2012). The anatomical and morphological differences of submersed and emergent macrophytes may result in specific adaptations to environments conditions. 
Differences created by littoral geomorphology, water level fluctuation, variable light, and anthropogenic influences create a wide range of habitats for emergent and submerged water plants, as well as for floating-leaved plants (Feldmann and Nöges, 2007; Sender, 2010). Research suggests that greatly limits primary production in lakes thus it is speculated that managing for light could aid in the technical fight against overgrowing (Dawson, 1981; Spence, 1981; Ali et al., 2011).

The aim of the study was to investigate whether decreases in light from riparian trees shading limits growth of aquatic plants in lakes. In addition, data was collected to assess the effects of duration of sun exposure on species composition, zonation and biomass of different groups of macrophytes in the studied lake. These data will aid in understanding shifts in the structure and composition not only of submerged macrophytes plant communities that are often described in the literature (Lu et al., 2013; Squires et al., 2002; Wersal and Madsen, 2013), but also communities of emergent macrophytes which are much less studied. Determining correlations between trends light conditions and colonization patters would inform management and restoration of eutrophic lakes being overgrown by aquatic vegetation.

\section{Materials and Methods}

Lake Czarne Sosnowickie $\left(51^{\circ} 31^{\prime} \mathrm{N}, 23^{\circ} 02^{\prime} \mathrm{E}\right.$ ) is located in the north-western part of Sosnowica commune, in the foothills of the western slope of the Garb Włodawski in north eastern Poland. It is located in the basin of rivers North - Piwonia - Tyśmienica Wieprz. The lake's catchment area is formed in the Quaternary formations, set on the Calcareous, reaching $23 \mathrm{~m}$ below water surface. Shallow banks are covered with a thin layer of sand (Harasimiuk et al., 1998). This lake is one of the seven deepest lakes in the area of the Lęczna-Włodawa Lakeland (eastern Poland). The surface area of the lake is 37,6 ha and the maximum depth is $15,6 \mathrm{~m}$.

The north and east shores of the lake are surrounded by pine forests mixed with birch and the south and southwest there is a swampy forest. The lake includes two small drainage ditches, which are the main cause of anthropogenic pressure on the lake. The reservoir is used for storage of water used by the fish farm in Sosnowica. Mid-forest location, paludification of the south shore and the difficult availability of the banks, makes it slightly seasonally used for tourist purposes (Fig. 1).

Because the lake was located in the midst of a forest, determination of research positions with various degrees of shading of the littoral zone was possible. The study was performed during the summer (in June and July) of 2013. The study was conducted in six transects I-III in the northern part (I - north - west, II - north, III - north - east) and IV-VI in the southern part of the lake (IV - south east, V - south, VI - south - west) (Fig. 1). The number and location of transects was associated with the greatest likeness of morphometric conditions in north and south parts of lake, as well as diversification of insolation conditions. Each of the transects started from the shoreline, and the distance into the lakes center depended on the range of macrophytes occurrence. In addition, in order to determine the total area occupied by macrophytes in the analyzed lake, another four transects on the eastern and western shores of the lake were established. GPS and sonar Elit no. 5 was used to determine the extent of macrophytes occurrence. Total phytolittoral cover was calculated on the basis of macrophyte analysis in horizontal transects, extending from the shoreline to the maximum colonization depth. The 
distribution of transects estimated by application of the formula MLT - minimal required number of transects (Jensén, 1977).

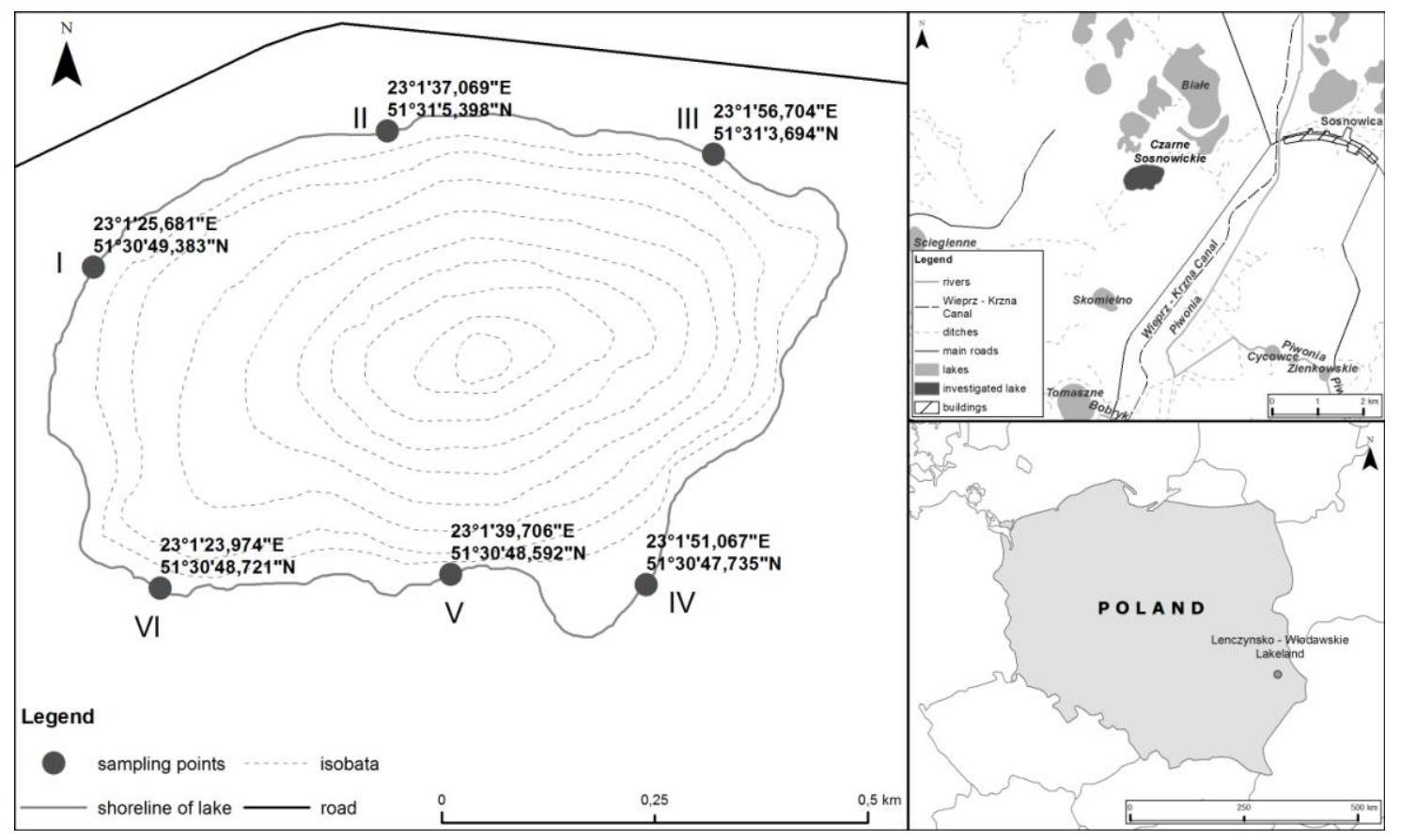

Figure 1. Localization of investigated Lake Czarne Sosnowickie and sampling points

Data from topographic maps at a scale of 1:10 000 and orthophotomaps, as well as field data were collected and processed using the software ArcGIS for Desktop 10.1.

The length of shadow, for every single sampling point, five times during the day (at 7am, 9am, 12am, 2pm and 4pm) was also calculated. The shadow model was made using GIS techniques (the Solar analysis of ArcGis desktop software). Moreover, the degree of shading $\left(S_{n}\right.$ - shading rate) of the horizontal transects was determined at 12 am, 15th of each month on the basis of the formula (adopted from Mander, 1995):

$$
\mathrm{S}_{\mathrm{n}}=\frac{s r}{B}\left[(H d \operatorname{ctg} \alpha / \sin \varphi /)-\left(L d-\frac{s k}{2}\right)\right]
$$

where:

$\mathrm{sr}$ - degree of belt plant compactness (\%)

$\mathrm{B}$ - width of the littoral zone (m)

$\mathrm{Hd}$ - height of trees (m)

$\alpha$ - angle of sunlight $\left({ }^{\circ}\right)$

$\varphi$ - the angle between the north-south direction, and the direction of the line the banks $\left({ }^{\circ}\right)$

$\mathrm{Ld}$ - distance of trees belt from water surface $(\mathrm{m})$

sk - factor depending on the shape and compactness the tree canopy (-)

At the same time in each transect qualitative and quantitative structure of emergent and submerged macrophytes (cover, abundance, biomass, number of species) and basic physical and chemical parameters of water (temperature, $\mathrm{pH}$, electrolytic conductivity, 
nitrate, phosphate, oxygen, visibility) were determined. The following instruments were used for determination of physical and chemical properties of water: OXI 330-oxymeter made by WTW (oxygen content, temperature), electronic conductivity meter made by Hanna (electrolytic conductivity), microchip Slandi SP300 pH-meter (water reaction). The content of biogenic nitrogen and phosphorus compounds was determined using the microchip Slandi photometer LF 205.

Analysis of emergent macrophytes included: species composition, density (ind. per $\mathrm{m}^{2}$ ), mean length and biomass of the species occurring in all research sites Phragmites australis (Cav.) Trin. ex Steud., as well as, total biomass $\left(\mathrm{g}_{\mathrm{dw}}\right.$ per $\left.\mathrm{m}^{2}\right)$, width and extent of rushes $(\mathrm{m})$. Measurements of submerged macrophytes were conducted at $0.5 \mathrm{~m}$ intervals from the shoreline to the maximum depth of their occurrence. Monitoring included analysis of species, total biomass $\left(\mathrm{g}_{\mathrm{dw}}\right.$ per $\left.\mathrm{m}^{2}\right)$ and share of each species in biomass, as well as the extent of occurrence. Each measurement was repeated 3 times.

Biodiversity of each group of macrophytes was supported by the index of ShannonWeaver (Hs) (Hennink and Zeven, 1991):

$$
\mathrm{H}_{\mathrm{S}}=-\Sigma\left(\mathrm{N}_{\mathrm{i}} \times \ln \mathrm{N}_{\mathrm{i}}\right)
$$

where $\mathrm{N}_{\mathrm{i}}$ is the relative abundance of species $\mathrm{i}$.

Floristic studies were carried out using the Bernatowicz floral rake, the floristic anchor and the sonar Elite no. 5 of LOWRENCE (Sender, 2012b).

The collected data set was analyzed statistically to determine arithmetic mean and standard deviation (SD). The parameters were compared with the use of t-test. To determine the strength of the relationship among factors Pearson's correlation coefficient was used. For the statistical analysis Statistica 5.1 StstSoft software was used.

\section{Results}

The analyzed positions with two distinguished parts of the lake were characterized by a small diversity of physico-chemical parameters. Higher values of the Secchi disk visibility and water temperature were found on the north side of the Lake, which was more exposed to the sun. The $\mathrm{pH}$ of the water was clearly alkaline. The rest of the analyzed physical and chemical parameters including: conductivity, hardness, $\mathrm{PO}_{4}, \mathrm{NH}_{4}$ and oxygen content achieved slightly higher values in the southern shore of the lake (Table 1). Differences between distinguished transects and physical and chemical parameters were not statistically significant $(T=0.02<\mathrm{T} \alpha=2.14, \mathrm{p}<0.05)$.

Table 1. Mean values of selected physical and chemical parameters in analyzed transects of Lake Czarne Sosnowickie

\begin{tabular}{|l|c|c|c|c|}
\hline Part of the lake & \multicolumn{2}{|c|}{ North shore } & \multicolumn{2}{c|}{ South shore } \\
\hline Factor & mean & \pm & mean & \pm \\
\hline Visibility $(\mathrm{m})$ & 0.86 & 0.04 & 0.705 & 0.055 \\
Temperature $\left({ }^{\circ} \mathrm{C}\right)$ & 26.55 & 1.25 & 25.05 & 0.05 \\
Water reaction $(\mathrm{pH})$ & 7.675 & 0.505 & 8.455 & 0.005 \\
Conductivity $\left(\mu \mathrm{S} \cdot \mathrm{dm}^{-}{ }^{3}\right)$ & 297.9 & 9 & 312 & 0.3 \\
$\mathrm{O}_{2}\left(\mathrm{mg} \cdot \mathrm{dm}^{-3}\right)$ & 6.29 & 3.56 & 12.6 & 0.4 \\
$\mathrm{Hardness}$ & 10.905 & 0.725 & 9.495 & 0.045 \\
$\mathrm{PO}_{4}\left(\mathrm{mg} \cdot \mathrm{dm}^{-3}\right)$ & 0.02 & 0.012 & 0.048 & 0.005 \\
$\mathrm{NH}_{4}\left(\mathrm{mg} \cdot \mathrm{dm}^{-3}\right)$ & 0.457 & 0.033 & 0.7895 & 0.0725 \\
\hline
\end{tabular}


In the investigated lake, macrophytes occupied 11 ha, which accounted for $29.9 \%$ of surface area of lake. The main component of phytolittoral was emergent macrophytes consisted almost $70 \%$ of total cover of macrophytes (Table 2).

Table 2. Characteristic of phytolittoral in Lake Czarne Sosnowickie

\begin{tabular}{|c|c|c|}
\hline \multirow[b]{2}{*}{ Factor } & \multicolumn{2}{|c|}{ Value } \\
\hline & ha & $\%$ \\
\hline Total phytolittoral surface & 11 & 29.2 \\
\hline Share of emergent macrophytes in phytolittoral & 7.51 & 68.3 \\
\hline Share of submerged macrophytes in phytolittoral & 3.52 & 32.09 \\
\hline Colonization depth of macrophyte occurence (m) & \multicolumn{2}{|c|}{2.5} \\
\hline Maximum depth of emergent macrophyte occurence (m) & \multicolumn{2}{|c|}{1.3} \\
\hline Mean width of rushes $(\mathrm{m})$ & \multicolumn{2}{|c|}{19} \\
\hline
\end{tabular}

Shading of littoral zone of the lake Czarne Sosnowickie was clearly differentiated. The area covered by shadows was highly dependent on the height of riparian trees and time of day. In the north, the trees reached a maximum height of $26 \mathrm{~m}$, and in the south $30 \mathrm{~m}$. The length of the shadow in the northern shore of the lake was low and ranged from $0.9 \mathrm{~m}$ to $1.77 \mathrm{~m}$. However, in the southern shore the shadow of the trees reached up to $15 \mathrm{~m}$ (Table 3).

Table 3. Length of the shadow (standard deviation, SD) in the following hours (15 days of the month 2013)

\begin{tabular}{|l|l|l|l|l|l|l|l|l|l|l|}
\hline & \multicolumn{9}{|c}{ JUNE } & \multicolumn{6}{c|}{ JULY } \\
\cline { 2 - 11 } & 7am & 9am & 12am & 2pm & 4pm & 7am & 9am & 12am & 2pm & 4pm \\
\hline I & $1.7 \pm 0.9$ & $1.5 \pm 0.3$ & $1.0 \pm 0.7$ & $1.25 \pm 0.02$ & $1.66 \pm 0.4$ & $1.9 \pm 0.6$ & $1.4 \pm 0.03$ & $0.9 \pm 1.01$ & $1.1 \pm 0.7$ & $1.7 \pm 1.01$ \\
II & $1.6 \pm 0.1$ & $1.56 \pm 0.02$ & $1.4 \pm 0.5$ & $1.6 \pm 0.3$ & $1.63 \pm 0.8$ & $1.6 \pm 0.5$ & $1.5 \pm 1.1$ & $1.3 \pm 0.4$ & $1.45 \pm 1.0$ & $1.77 \pm 1.3$ \\
III & $1.7 \pm 0.2$ & $1.4 \pm 0.2$ & $1.2 \pm 0.09$ & $1.22 \pm 0.1$ & $1.31 \pm 0.2$ & $1.4 \pm 1.1$ & $1.2 \pm 0.7$ & $1.0 \pm 0.2$ & $1.1 \pm 0.5$ & $1.6 \pm 1.1$ \\
IV & $7.9 \pm 2.1$ & $7.8 \pm 1.7$ & $7.2 \pm 0.9$ & $7.9 \pm 1.4$ & $8.9 \pm 1.3$ & $7.5 \pm 1.1$ & $7.2 \pm 1.0$ & $7 \pm 0.5$ & $7.3 \pm 1.4$ & $7.9 \pm 2.3$ \\
V & $7.7 \pm 1.1$ & $7.2 \pm 0.1$ & $6.8 \pm 1.1$ & $7.3 \pm 2.9$ & $7.6 \pm 1.0$ & $7 \pm 1.8$ & $6.2 \pm 1.6$ & $6 \pm 0.8$ & $6.5 \pm 1.1$ & $8.1 \pm 0.7$ \\
VI & $12.9 \pm 3.2$ & $11 \pm 2.5$ & $10.1 \pm 3.5$ & $10.5 \pm 4.3$ & $12.9 \pm 1.2$ & $14 \pm 2.6$ & $11.6 \pm 5.8$ & $10 \pm 3.8$ & $11 \pm 0.6$ & $15.9 \pm 3.5$ \\
\hline
\end{tabular}

The degree of shading of the zone covered by macrophytes was varied in the different transects of the lake. In the northern shore of the lake shading rate was about $3 \%$, while in the southern approximately $30 \%$. Along the northern shore, on average only $6 \%$ of rushes were covered by tree shade, in contrast, on the southern shore shade covered up to $89 \%$ of rushes.

In all transects, shade completely covered the zone occupied by all groups of macrophytes. Only at one investigated site was the range of the rushes smaller than the area of shading. The length of transects, covering with colonization depth of macrophytes, was much greater than the shade of nearby riparian trees and ranged from $20 \mathrm{~m}$ in the southern shore to $65 \mathrm{~m}$ in the northern shore (Fig. 2). There was strong correlation between the length of the littoral zone shading, and the colonization of emergent macrophytes $\left(R^{2}=-0.84 ; \mathrm{p}<0.05\right)$. 


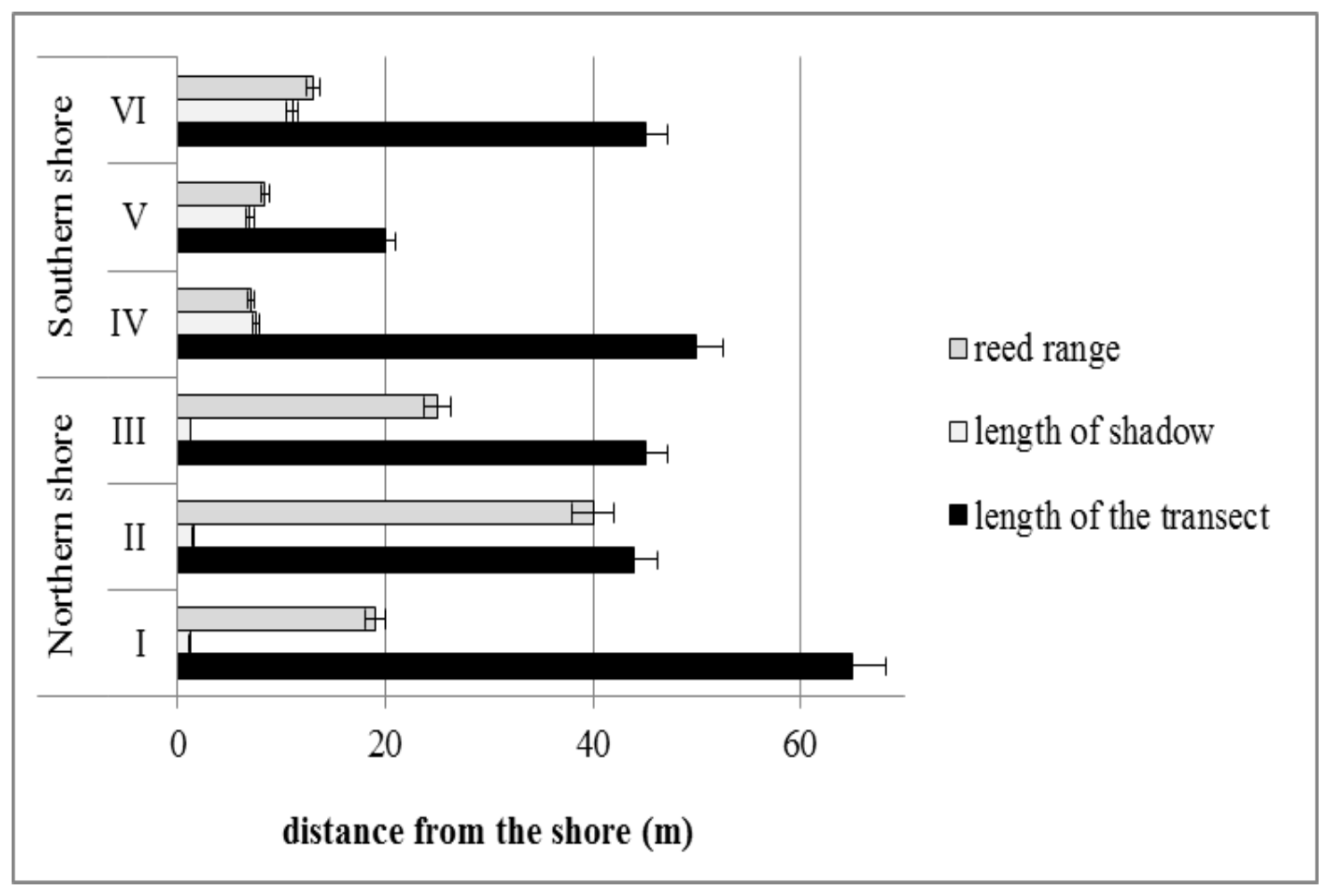

Figure 2. The length of shadow, rushes width and length of the analyzed transects (mean values) in Lake Czarne Sosnowickie

The entire shallow littoral zone was inhabited by rushes. Emergent macrophytes developed from the shoreline, until up to $1.3 \mathrm{~m}$ depth in the northern shore (Fig. 3). The width of belt rushes was clearly differentiated in the northern shore of reaching an average width of $28 \mathrm{~m}( \pm 8.8)$, while in the southern shore $9 \mathrm{~m}( \pm 2.6)$ and these differences were statistically significant $(\mathrm{T}=2.85>\mathrm{T} \alpha=2.77, \mathrm{p}<0.05)$.

As colonization depth increased so did diversity of species and total community biomass of macrophyte in the analyzed parts of the lake Czarne Sosnowickie. Emergent and floating plants achieved significantly higher values in the northern shore of the lake. Only submerged macrophytes, despite a small range of distribution, in the southern shore achieved higher values of biomass. Differences in their biomass were not statistically significant $(\mathrm{T}=1.35<\mathrm{T} \alpha=2.57, \mathrm{p}<0.05)$ (Fig. 4).

Plants with floating leaves grew equally well in both of the analyzed sections of the lake. In the northern part of the lake (7 species), there was a slightly greater numbers of free floating and floating-leaved plants and biomass of emergent macrophytes ranged from $21 \mathrm{~g}_{\mathrm{dw}} \cdot \mathrm{m}^{-2}$ (III transect) to $34 \mathrm{~g}_{\mathrm{dw}} \cdot \mathrm{m}^{-2}$ (II transect). In contrast, on the southern shore there were only 4 species and their biomass ranged from $10 \mathrm{~g}_{\mathrm{dw}} \cdot \mathrm{m}^{-2}$ (VI transect) to $19 \mathrm{~g}_{\mathrm{dw}} \cdot \mathrm{m}^{-2}$ (V transect) (Fig. 4). Differences in biomass and the colonization depth of these groups of macrophytes at different positions were not statistically significant $(\mathrm{T}=1.75<\mathrm{T} \alpha=2.57, \mathrm{p}<0.05)$.

Both the northern and southern shore of the lake was under the influence of riparian trees shade. The amount of light had a significant impact on the structure of emergent macrophytes. It turned out that in the more shady places (southern shore) helophytes density and biomass was lower. But in these transects shoots of emergent macrophytes 
were longer (Pearson 0.92, the correlation very large) suggesting high competition for light.

In the northern shore of the lake rushes species diversity, biomass and colonization depth were generally higher than along the southern shore (Table 4).
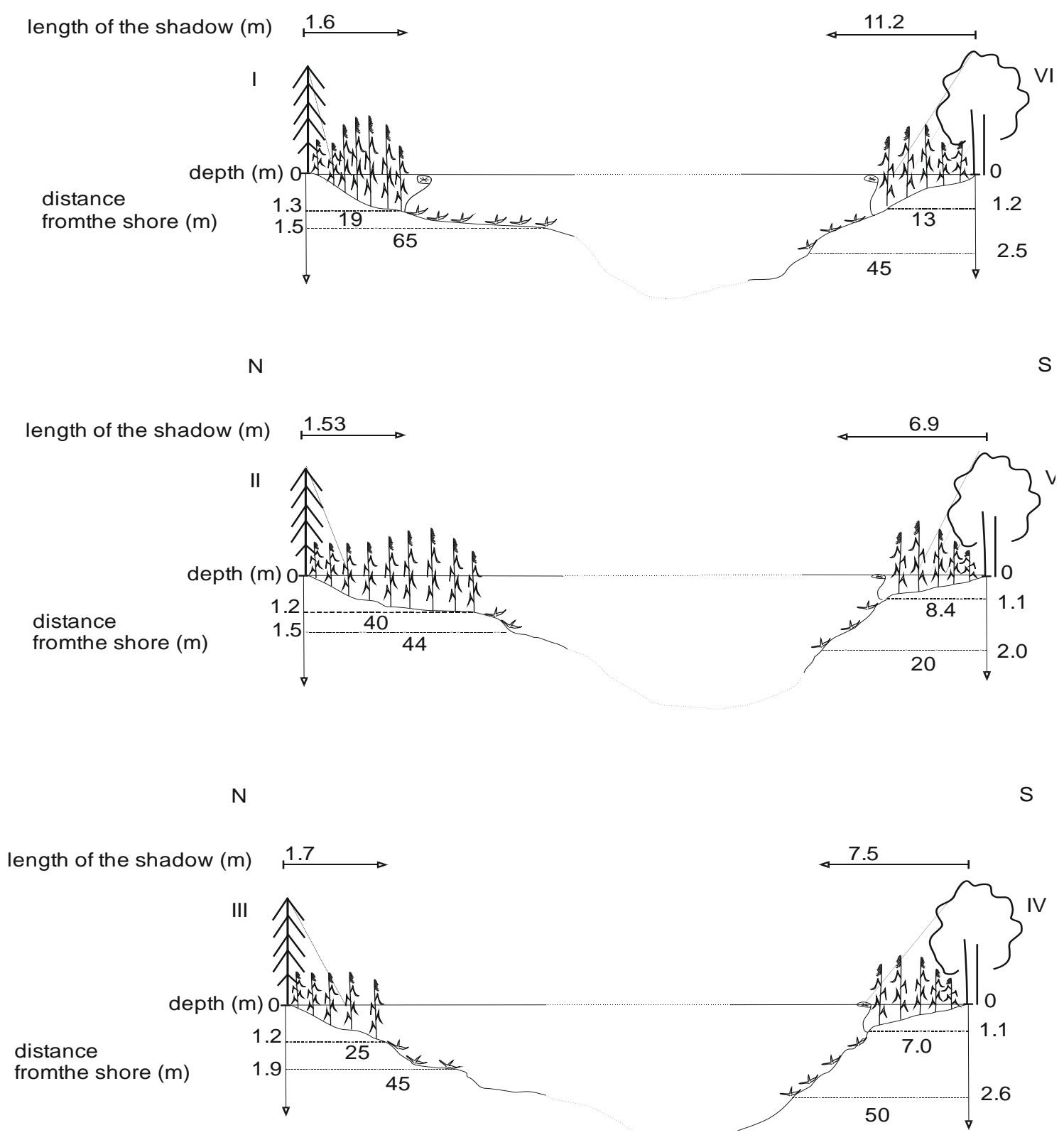

Figure 3. Distribution of macrophytes in the northern and southern shore of the Lake Czarne Sosnowickie

Differences of some morphometrical features of Phragmites australis (Cav.) Trin. ex Steud., and the fact that the species occurs in all positions of study were clear and statically significant $(\mathrm{T}=10.3>\mathrm{T} \alpha=4.3, \mathrm{p}<0.05)($ Table 4). 


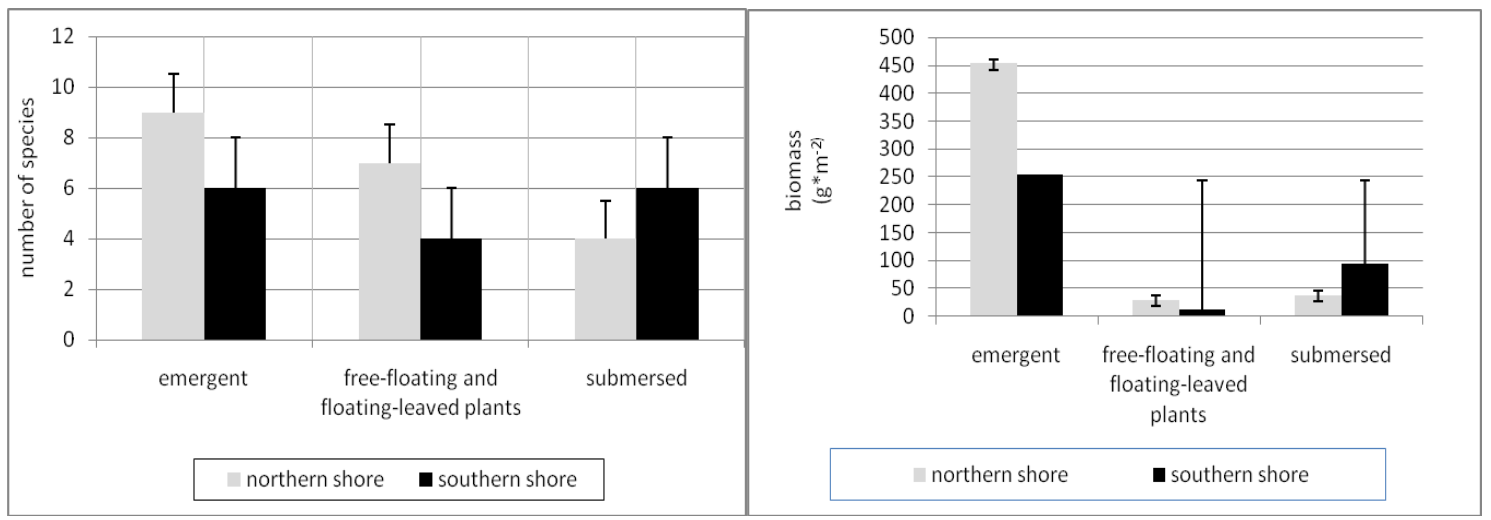

Figure 4. Mean number of macrophyte species and their biomass in distinguish parts of shore

Table 4. The structure of emergent macrophytes in studied transects of Lake Czarne Sosnowickie

\begin{tabular}{|c|c|c|c|c|c|c|}
\hline Transects & \multicolumn{3}{|c|}{ Northern shore } & \multicolumn{3}{|c|}{ Southern shore } \\
\hline Feature & $\begin{array}{c}\text { North-west } \\
\text { (I) }\end{array}$ & $\begin{array}{l}\text { North } \\
\text { (II) }\end{array}$ & $\begin{array}{l}\text { North- } \\
\text { east (III) }\end{array}$ & $\begin{array}{c}\text { South- } \\
\text { west (VI) }\end{array}$ & $\begin{array}{l}\text { South } \\
(\mathbf{V})\end{array}$ & $\begin{array}{c}\text { South-east } \\
\text { (IV) }\end{array}$ \\
\hline $\begin{array}{c}\text { Dominant species in } \\
\text { biomass }\end{array}$ & \multicolumn{3}{|c|}{ Typha angustifolia $L$. } & \multicolumn{3}{|c|}{$\begin{array}{c}\text { Phragmites australis (Cav.) Trin. ex } \\
\text { Steud. }\end{array}$} \\
\hline $\begin{array}{l}\text { Width of belt rushes } \\
(\mathrm{m})\end{array}$ & $19 \pm 2.8$ & $40 \pm 5.1$ & $25 \pm 2.2$ & $13 \pm 1.9$ & $9,4 \pm 0.9$ & $7 \pm 1.1$ \\
\hline $\begin{array}{l}\text { Max depth of rushes } \\
\text { occurrence }(\mathrm{m})\end{array}$ & 1.3 & 1.2 & 1.2 & 1.2 & 1.1 & 1.1 \\
\hline $\begin{array}{l}\text { Density of helophytes } \\
\text { (ind. per } \mathrm{m}^{2} \text { ) }\end{array}$ & 76 & 64 & 60 & 56 & 38 & 48 \\
\hline Number of species & 9 & 7 & 5 & 4 & 3 & 2 \\
\hline $\begin{array}{c}\text { Mean length of } \\
\text { Phragmites australis } \\
(\mathrm{m})\end{array}$ & $1.8 \pm 0.2$ & $1.8 \pm 0.5$ & $1.9 \pm 1.2$ & $2.1 \pm 0.7$ & $2 \pm 0.1$ & $2.3 \pm 0.4$ \\
\hline $\begin{array}{l}\text { Biomass of single } \\
\text { shoot of Phragmites } \\
\text { australis }\left(\mathrm{g}_{\mathrm{dm}}\right)\end{array}$ & $15.2 \pm 2.4$ & $\begin{array}{l}13.9 \\
\pm 1.3\end{array}$ & $14.2 \pm 1.7$ & $17.4 \pm 3.4$ & $18.2 \pm 2.2$ & $18.8 \pm 4.1$ \\
\hline $\begin{array}{l}\text { Total biomass of } \\
\text { rushes }\left(\mathrm{g}_{\mathrm{sm}} \cdot \mathrm{m}^{-2}\right)\end{array}$ & $516.8 \pm 22$ & $\begin{array}{c}435 \\
\pm 19.8\end{array}$ & $408 \pm 25.6$ & $\begin{array}{l}302.4 \\
\pm 17.7\end{array}$ & $\begin{array}{l}199.2 \\
\pm 11.5\end{array}$ & $259 \pm 10.4$ \\
\hline $\begin{array}{l}\text { Index of Shannon- } \\
\text { Weaver }\end{array}$ & 1.5 & 1.4 & 1.4 & 1.1 & 0.9 & 0.6 \\
\hline
\end{tabular}

The low density of emergent macrophytes caused that biomass of shoots was higher. Dependency statistically significant $(\mathrm{T}=5.2>\mathrm{T} \alpha=3.3, \mathrm{p}<0.05)$. 
There was a strong correlation between length of shadow and biomass of emergent macrophytes (Pearson 0.99). The smaller shadow caused the higher total biomass of rushes. Higher correlation was also noted between the width of helophytes and the length of shadow. If the range of helophytes decrease, shadow will increase (Pearson 0.76).

Shannon-Weaver index confirmed significant variation within this group of macrophytes (Table 4).

Higher colonization depth of submerged macrophytes was in transects on the south side of lake (average $2.5 \mathrm{~m}$ ). On the northern shore the maximum depth of macrophytes occurrence was only $1.5 \mathrm{~m}$ (Fig. 3). The highest diversity of species (7) and biomass $\left(178.8 \mathrm{~g}_{\mathrm{dw}} \cdot \mathrm{m}^{-2}\right)$ occurred in the southern shore in a depth ranging from 1.5 to $2.0 \mathrm{~m}$. In the northern shore the highest number of submerged species (5) was observed in a depth ranging from 1 to $1.5 \mathrm{~m}$ and their biomass was $157.3 \mathrm{~g}_{\mathrm{dw}} \cdot \mathrm{m}^{-2}$ (Fig. 5).
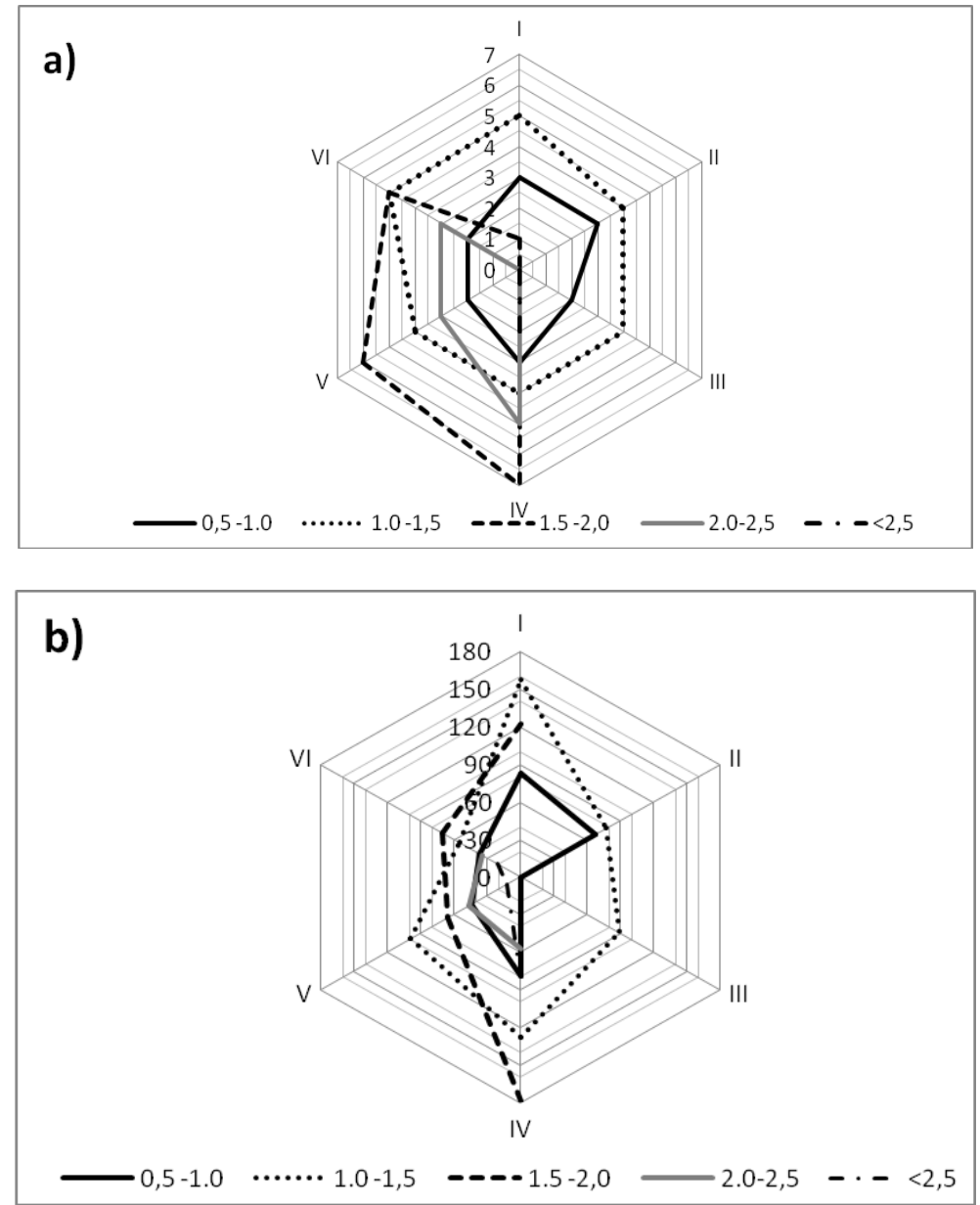

Figure 5. a) number of plant species and $\boldsymbol{b}$ ) biomass of submerged macrophytes in particular depths of Lake Czarne Sosnowickie

The same submerged plant species occurred in each investigated part of the lake. Only their share in the biomass on particular depths and transects was different (Fig. 5, Table 5). 
Table 5. Share of submerged macrophyte species in biomass and Shannon-Weawer index for individual depths

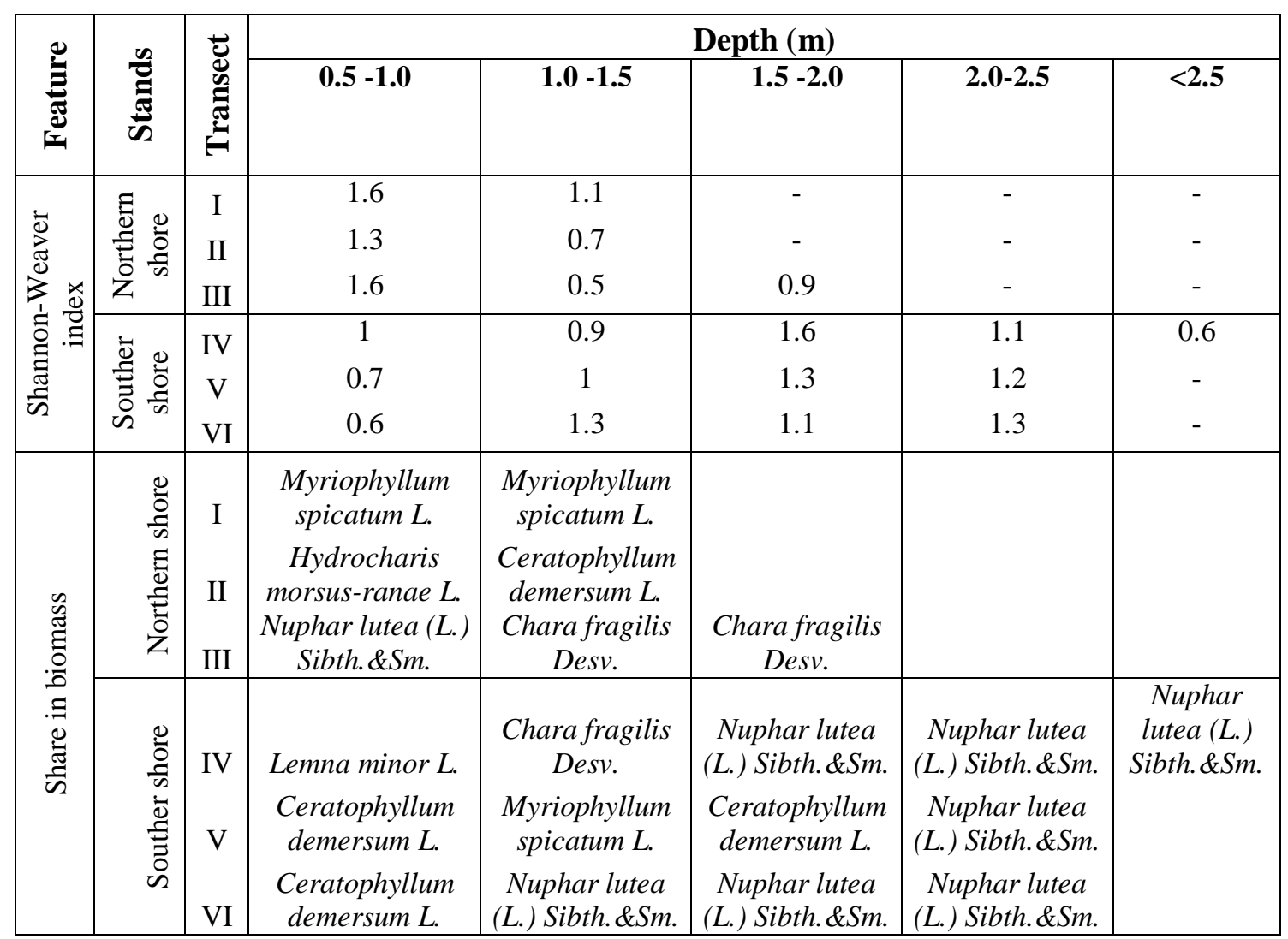

\section{Discussion}

The main question of this study was to determine whether riparian trees limit growth of aquatic plants in lakes. Data showed that it depends on the group of macrophytes and range of shadow impact. The whole lake was surrounded by forest and similar water conditions on all shores were confirmed by chemical analysis. Slightly higher values of the analyzed physical and chemical parameters were in the southern shore of the lake. The probable cause of this phenomenon was an extinct peat bog, transformed by drainage (Szymczyk and Szyperek, 2005).

An unambiguous determination of the impact of shading on the growth of macrophytes is very difficult. Natural conditions are variable and usually applied to a wide variety of factors. Riparian vegetation limits access of light to the lake only in the shallow part of the littoral zone. Studies have shown that a large amount of penetrating sunlight positively affects emergent aquatic vegetation. First of all, less shading is conducive to the development of emergent and free-floating plants. In these low-light stands there was a higher species diversity, colonization depth and biomass. They were much higher than recorded for rivers in south Estonia with similar shade conditions (Mander et al., 1995). Despite the lower visibilities, higher species diversity and biomass, the submerged macrophytes occurred the southern shore of the investigated lake. Experimental studies on the effects of shading carried out on two species of submerged macrophytes confirmed their disappearance in complete shade, as well as relatively good growth under moderate shading (LU et al., 2013). Generally, in the 
studied lake, submerged macrophytes disappeared in the area of floating leaves' plants. The most deeply penetrated macrophyte species tolerant of low light conditions were Myriophyllum spicatum L. and Ceratophyllum demersum L. (Lougheed et al., 2001). Submerged macrophytes in investigated lake with an area approximately 4 ha were not dependent on the shading caused by the surrounding forest. Their structure and development are related to the conditions in the lake. As a rule, submerged macrophytes grow to a depth of two to three times the Secchi disc depth (Chambers and Kalff, 1985). In the studied lake almost all zones of submerged macrophyte occurrence were not dependent on shading from shoreline vegetation. Only macrophytes occurring in the area of 0.5-1 m depth were influenced by shading. In the northern shore, in spite of better conditions of sunlight, due to the lush growth of rushes, submerged macrophytes were losing the competition. In the southern shore where the rush vegetation achieve lower density and extent of occurrence, submerged macrophytes developed better. In these areas, there was a greater variety of species and biomass. Apart from the impact of the shadow zone, along the northern shore of the lake the number of species decreased, while in rose along the southern shore, just like biomass. Free-floating plants may grow well in low transparency of water (Feldmann and Nöges, 2007). In the investigated lake, this group of plants developed better (higher species richness and higher biomass) along the northern shore, with better light condition. This group of macrophytes with dense reed stands can modify habitat conditions for other species in a very strong way and even eliminate them (Feldmann and Nöges, 2007). Emergent macrophytes are a group of aquatic plants less dependent on the light conditions occurring in water (Lacoul and Freedman, 2006). The amount of light reaching them depends on the environment of the lake.

Usually, higher rushes species diversity, biomass and extent of occurrence were reached in the northern shore of the lake. This result suggests more favourable conditions for this group of plants developing in shadier areas. Typha angustifolia $L$. was a dominant species in the northern shore. This species is usually considered an indicator of mineral substrate in meso- to eutrophic water bodies (Zarzycki, 1984). In the southern shore of the lake, the organic substrate was dominated by Phragmites australis (Cav.) Trin. Ex Steud. In general, the best habitat conditions for the development of this group of macrophytes were in the northwestern and southwestern part of the lake. It was supported by the configuration of lake basin, creating favourable conditions for their spread (Gasith and Hoyer, 1998).

Thus, the possibility of using coastal vegetation as a tool for dealing with lake overgrowth may not be reasonable as data from this study suggests that shading does seem not to play a significant role in development of macrophyte communities. In bigger lakes interactions are local, whereas in rivers the management of tree vegetation might control their overgrowing (Mander et al., 2005).

Acknowledgements. The author wish to thank Magda Garbowski from Colorado State University for English revision of the text, as well as all students from Department of Landscape Ecology and Nature Protection who participated in these studies. 


\section{REFERENCES}

[1] Ali, M. M., Hassa, S. A., Shaheen, A. M. (2011): Impact of riparian trees shade on aquatic plant abundance in conservation islands. - Acta Botanica Croatica 70 (2): 245258.

[2] Barko, J. W., Adams, M. S., Clesceri, N. L. (1986): Environmental factors and their consideration in the management of submersed aquatic vegetation: review. - Journal of Aquatic Plant Management 24: 1-10.

[3] Bernatowicz, S. (1966): The effect of shading on the growth of macrophytes in lakes. Polish Journal of Ecology (former Ekol. Pol.) 2431, 14, 32: 605-616.

[4] Chambers, P. A., Kalff, J. (1985): Depth distribution and biomass of submerged aquatic macrophytecommunities in relation to Secchi depth. - Canadian Journal of Fisheries and Aquatic Sciences 42: 701-709.

[5] Chełmicki, W. (2001): Wather: resurs, degradation, protection (Woda: zasoby, degradacja, ochrona). -Scientific Publisging PWN Warszawa, 305.

[6] Dawson, F. H. (1981): The reduction of light as a technique for the control of aquatic plants an assessment. - Proceedings of the Association of Applied Biologists Symposium Aquatic Weeds and their Control, Oxford, 157-164.

[7] Feldmann, T. (2012): The structuring role of lake conditions for aquatic macrophytes. A thesis for applying for the degree of doctor of Philosophy in Hydrobiology. Estonian University of Life Sciences, Tartu.

[8] Feldmann, T., Nöges, P. (2007): Factors controlling macrophyte distribution in large shallow Lake Vortsjarv. - Aquatic Botany 87: 15-21.

[9] Gasith, A., Hoyer, M. V. (1998): Structuring role of macrophytes in lakes: changing influence along lake size and depth gradients. In: Jeppesen, E., Sondergaard, M., Sondergaard, M., Christoffersen, K., (eds.) The Structuring Role of Submerged Macrophytes in Lakes. - Springer, New York, 381-392.

[10] Harasimiuk, M., Michalczyk, Z., Turczyński, M. (1998): Łęczna-Włodawa Lakes. Natural monography (Jeziora łęczyńsko-włodawskie. Monografia przyrodnicza). Publishing. Biblioteka Monitoringu Środowiska Lublin.

[11] Hennink, S., Zeven, A. C. (1991): The interpretation of Nei and Shannon-Weaver within the population variation indices. Euphitica 51: 235-240.

[12] Jensén, S. (1977): An objective method for sampling the macrophyte vegetation in lakes. - Vegetatio 33:107-118

[13] Lacoul, P., Freedman, B. (2006): Environmental influences on aquatic plants in freshwater ecosystems. - Environmental Reviews 14: 89-136.

[14] Lehmann, A., Lachavanne, J. (1999): Changes in the water quality of Lake Geneva indicated by submerged macrophytes. Freswater Biology 42: 457-466.

[15] Lougheed, V. L., Crosbie, B., Chow-Fraser, P. (2001): Primary determinants of macrophyte community structure in 62 marsh across the Great Lakes basin: latitude, land use and water quality effects. - Canadian Journal of Fisheries and Aquatic Sciences 58: 1603-1612.

[16] Lu, J., Wang, Z., Xing, W., Lui, G. (2013): Effect of substrate and shading on growth of two submerged macrophytes. - Hydrobiologia 700: 157-167.

[17] Madsen, T. V., Brix, H. (1997): Growth, photosynthesis and acclimation by two submerged macrophytes in relation to temperature. - Oecologia 110: 320-327.

[18] Mander, Ü. (1995): Riparian buffer zones and buffer strips on stream banks: dimensioning and efficiency assessment from catchments in Estonia. In: Eiseltová, M., Biggs, J., (Eds.), Restoration of Stream Ecosystems.- IWRB Publication Slimbridge, Gloucester, UK, 37: 45-64.

[19] Mander, Ü., Hayakawa, Y., Kuusemets, V. (2005): Riparian buffer zone in agricultural watersheds. Purification processes, ecological functions, planning and design of riparian buffer zones in agricultural watersheds.- Ecological Engineering 24(5):421-432. 
[20] Mander, Ü., Kuusemets, V., Ivask, M. (1995): Nutrient dynamics of riparian ecotones: a case study from the Porijõgi River catchment, Estonia. - Landscape and Urban Planning 31 (1-3): 333-348.

[21] Sedvik, T. O., Celik, K. (2014): The effects of certain physical and chemical variables on the succession of the phytoplankton in the shallow Cagis pond (Balıkesir, Turkey). Ekoloji 23(93): 27-35

[22] Sender, J. (2010): Long - term changes of plant water vegetation in the macrophyte tape lakes on Łęczna-Włodawa Lakeland (Długoterminowe zmiany struktury roślinności wodnej w makrofitowych jeziorach na Pojezierzu Łęczyńsko-Włodawskim) - Annales UMCS, Agricultura 65(2):58-67.

[23] Sender, J. (2012): Quantitative investigations of vascular flora in deep and shallow eutrophic lake. - TEKA Commission of Protection and Formation of Natural Environment - OL PAN, 9: 206-214.

[24] Sender, J.(2012b): The dynamics of macrophytes in a lake in an agricultural landscape.Limnological Review DOI 10.2478/v10194-011-0049-6; 2: 93-100.

[25] Spence, D. H. N. (1981): Light quality and plant response under water. In: Smith H. (ed.), Plants and the day light spectrum. - Academic Press, New York, 245-275.

[26] Squires, M. M., Lesack, L., Huebert, D. (2002): The influence of water transparence on the distribution and abundance of macrophytes among lakes of Mackenzie Delta, Western Canadian Arctic.- Freshwater Biology 47: 2123-2135.

[27] Szymczyk, S., Szyperek, U. (2005): The role of peatlands in reducing nutrient runoff from agricultural catchment, (Rola torfowiska w ograniczaniu odpływu składników biogennych ze zlewni rolniczej).- Zeszyty Problemowe Nauk. Rolniczych 506.

[28] Wersal, R. M., Madsen, J. D. (2013): Influence of light intensity variations on growth characteristics of Myriophyllum aquaticum. - Journal of Freshwater Ecology 28(2): 147164.

[29] Zarzycki, K. (1984): Ecological indicator numbers of vascular plants in Poland, (Ekologiczne liczby wskaźnikowe roślin naczyniowych Polski). - Publising PAN. Instytut Botaniki Kraków. 